\title{
Digital Divide and Poverty Eradication in the Rural Region of the Northern Peninsular Malaysia
}

\author{
Sharifah Rohayah Sheikh Dawood, Suriati Ghazali and Narimah Samat \\ Geography Section, School of Humanities, Universiti Sains Malaysia, Penang, Malaysia
}

Received: 2018-10-28 Accepted: 2019-08-04

Keywords:

poverty;

digital divide;

Northern Region,

Malaysia

Corespondent Email:

sdawood@usm.my

\begin{abstract}
Although Malaysia has achieved economic development in various sectors, poverty still remains as a problem in many areas. One of the ways to eliminate poverty is through information and communication technologies (ICTs) which is often promoted as central to reviving and sustaining regional communities. In the context of Malaysia, however, a gap in access to ICTs exists between the level of communication in urban and rural areas. While various initiatives have been taken to close the digital gaps, more efforts are needed especially in rural areas. This paper intends to explore the extent to which ICTs in rural areas of northern Peninsular Malaysia can raise the socioeconomic development of the communities there. Questionnaires and in-depth interviews were used and focus is given to analyze the role of ICTs in poverty reduction processes upholding regional developments. Particular emphasis was given to explore the access to ICTs and the extent to which it affects daily activities and economic development of the communities. It was observed that solving common causes for the communities' access and socioeconomic growth needs strategic implementation of policies at the central core and pragmatic implementation of actions at the grass roots level. pragmatic implementation of actions at the grass roots level.
\end{abstract}

(c) 2019 by the authors. This article is an open access article distributed under the terms and conditions of the Creative

Commons Attribution(CC BY NC) licensehttps://creativecommons.org/licenses/by-nc/4.0

\section{Introduction}

In the past few decades, technological advancement especially of the information and communication technologies (ICTs) has spread immensely across regions with profound transformational effects. In this respect, ICTs have played a significant role in the economic growth and structural change. Through economic growth, these technologies have led to the improvement in welfare and living standards of residents through the contribution in economic growth. It was stated that the expansion of computerization by the mid2000 s is deemed to increase pressures in terms of skill requirements among the world societies (Spitz-Oener, 2006). This relates to what Manuel Castells (2009) called the 'network society', whereby he describes about the new behavior and organization solutions are based on the social appropriation of ICTs that is forming within societies. In the network society the relationships of production and consumption (economic behavior), power (sociopolitical) and human experience (sociocultural and environment) are powered and shaped by global digital technologies (see Castells \& Gonzalez, 2014 \& Castells \& Himanen, 2014). Therefore, the diffusion of ICTs among people is highly dependent on their connectedness (media literacy), economic means (command of resources) and also autonomy (basic skills) (Mendonca, Crespo \& Simoes, 2015). Following the Sustainable Development Goals (SDGs) that has replaced the Millennium Development Goals (MDGs) in recent years, the United Nations has heightened the role of ICTs in accelerating the achievement of the goals by 2030. In this notion, ICTs and broadband are being utilized significantly with strong purpose to bring improvements in the communities' life in terms of business development and agricultural production, as well as education and health (unsdsn.org).

However, the gap between developed and developing nation as well as rural and urban areas is still a prevalent issue that needs to be addressed when it comes to the level of ICTs penetration into the societies. In this respect, the notion of a digital divide comes into perspective, whereby it addresses the issues of physical access to ICTs, education and technological savvy, as well as cultural and sociopolitical empowerment (Nemer, 2015). By definition, a digital divide is an economic and social inequality in the access to, the use of, or the impact of ICTs. This divide can refer to inequalities between individuals, businesses, households, or geographic areas. Thus, the phenomenon describing differences in access to the Internet and the information is referred to as the digital divide. However, as noted by Bednarczyk (2014), the digital divide is usually defined on two aspects: material and immaterial. The material plane addresses the physical access to a computer and 
the Internet by the person (first-order digital divide); and the immaterial plane encompasses the knowledge, motivations and needs fulfilled by the access (secondorder digital divide) (Bednarczyk, 2014). In many countries, the digital divide is an equality problem that also reflects the poverty of certain cities/communities in many countries. For instance, Internet access has a deeper penetration among wealthier sectors than the poorer sectors of a population. In some situation, low education attainment results in a low income and lesser opportunities for Internet access. Hence, the following groups are most vulnerable to digital exclusion: the older adults, pensioners and the retired, people with low education, the unemployed, farmers and residents of rural areas, those who are poor and living on welfare, and the disabled.

There is also a generational gap and evidently, a lack of infrastructure as a key issue to understanding the situation of digital divide especially for areas between the urban and the rural. In some cases, there are communities who are lacking the skills on digital literacy skills or they are simply unable to afford a digitally enabled device or a contract for an Internet service provider (ISP). This strengthens the association between financial exclusion and social exclusions (Warren, 2007; Chen \& Wellman, 2005) that closely affect the process of digital divide. In this respect, many countries including Malaysia have taken various actions to reduce the digital gap between communities. Since the year 2000, the government of Malaysia has taken various initiatives to reduce the digital gap by implementing tele-centers (TC) in many locations. Almost 2,500 TC are located in rural and suburban areas of the country. The introduction of the TC was expected to develop the rural areas and their population through the adoption of ICTs, leading residents to more similar levels of exposure and learning opportunities just as for those communities living in the urban areas.

This paper seeks to explore the nature of digital divide in the rural areas of the northern region, Peninsular Malaysia particularly with respect to the role and level of ICTs accessibility, individual knowhow and capabilities; as well as whether or not this affects their socioeconomic conditions and helps to reduce the incidence of poverty in the region. It also aims to shed some lights on the extent of how the communities engage with ICTs in their daily business activities and networking. The study was conducted from January, 2017 to May 2017 in the Kuala Muda district of Kedah, Malaysia, focusing on two areas: (a) the village of Tanjung Dawai (TD) and, (b) city of Sungai Petani (SP). The two locations were chosen for questionnaire survey in order to provide a comparative study of rural and urban area with respect to ICTs access and influence on socioeconomic development. Further in-depth interviews were also conducted with some of the selected informants in the TD village. The villagers' perceptions on the programs implemented were deemed necessary and important to evaluate the nature of the program, its accessibility and effectiveness to the communities.

\section{Digital Divide, Internet Access and Poverty Eradication}

Many scholars have given attention to the topics of digital divide, digital exclusion and digital inequalities and this work has received considerable attention from both national and international policy makers and scholars from various disciplines. These including literatures written from the field of human geography (see Warren, 2007; Malecki, 2003; Riddlesden \& Singleton, 2014), sociology (White \& Selwyn, 2013; Nephew Hassani, 2006; Blank \& Groselj, 2015), and public policy (Skerrat, 2013; Prieger, 2013). Nevertheless, there are limited research exists on rural perspectives regarding digital accessibility and challenges. The Organization for Economic Co-operation and Development (OECD) has defined the digital divide as "the gap between individuals, households, businesses and geographic areas at different socioeconomic levels with regard to both their opportunities to access ICTs and to their use of the internet for a wide variety of activities" ( $\mathrm{p}$. 5). In addition, DiMaggio et al. (2001, p. 3) stated that the digital divide is also referred to as "inequalities in access to the internet, extent of use, knowledge of search strategies, and quality of technical connections and social support". Thus, as noted by Sparks (2013, p. 8 ), it is a term used to include a wide range of social differences in the access to and use of digital equipment and services, especially the ability to access the Internet in terms of both physical connection and facility of use.

Nowadays, ICTs are universally accepted as powerful tools for development, particularly economic growth and social development. The process of implementing ICTs has increasingly influenced the socioeconomic context in many countries with respect to current development in recent years. This has been revealed by many scholars and government-sponsored studies that focused on the physical access to technology as the solution to digital divide (see Loader \& Keeble, 2004: Correa, 2008; Chinn \& Fairlie, 2004; van Dijk, 2006; Caspary \& O’Conor, 2003; Rashid, 2016). For instance, in many developing countries, governments turn to ICTs as a strategy for bridging the digital divide between rural and urban communities, and as well as to make sure in improving the living conditions of the rural population (Muhammad Sani Bashir et al. 2011). In this sense, ICTs are able to assist a much more transparent, speedy, and efficient interaction between the communities, businesses and other agencies. When ICTs are used to narrow the digital gap, the rural population has the opportunity to avail themselves towards a better quality of life than before. However, these people are often unaware of their entitlements 
and rights, as well as knowing the availability and provision of various government schemes and services on ICTs facilities. The urbanization process in the rural areas through the expansion of cyberspace and digital connectivity would be more successful if several factors are taken into careful consideration by the respective governance. These factors include the local conditions, such as the physical state of the area, its primary economy, social and cultural norms, and the political aspects.

It has to be noted that in some rural areas, farmers can actually access information on market prices or other services, and workers can obtain information on available jobs through info kiosks or even with the help of mobile phones. When it comes to the sale of produce, timing is often a crucial factor. However, such interventions can happen only when accompanied by other supporting infrastructure such as storage facilities, access to roads and competitive markets, including the global market. In this case, there are many rural areas which are connected through the initiative known as Wifi Village or wireless village using Internet through broadband and wireless technology. As in Malaysia, this initiative is part of the National Broadband Initiative launched by the government in 2010 with the aim of increasing the penetration of household broadband to $50 \%$ by 2020 (SKMM, 2010). In parallel with the globalization era, the Internet is a source and medium for global knowledge, and it has the ability to disseminate various forms of communication in a more speedy and interactive way. Malaysian communities are also not left behind in using the technology as part of their lifestyle. The emergence of broadband is realized as one of the contributors in engaging Malaysians to use the Internet. In Malaysia, broadband entered the market in 2005 with a penetration level of $1.9 \%$ (Ishak et al. 2007).

Recognizing the fact that the Internet has become important part of today's life, the government has intensified efforts to provide broadband Internet access throughout the country. These efforts include the opening of the 1Malaysia Internet Center (PI1M), which is part of an initiative implemented through the Malaysian Communications and Multimedia Commission (MCMC). The MCMC has taken various actions to encourage the local communities to explore and use the technology in day -to -day activities, which has been one of the agendas since the national Eighth Malaysia Plan (RMK-8), with the hope of reducing the digital gap. One of the strategies here is through the implementation of Medan Info Desa under the Ministry of Rural Development, including the Komuniti IT Selangor (KITS) under the state government, E-masjid Melaka, IT project of Ketengah and others. The sociodigital inclusion initiative was also introduced in 2010 to expand the usage of ICTs in rural areas and to expose the rural residents to ICTs besides instilling the ICTs usage in their daily life. Meanwhile the Ministry of Energy, Water and Communication (KTAK) incentive was tasked with reducing the digital gap among communities through the implementation of the Pusat Internet Desa (PID) (Zurinah et al., 2016). The initiative of the PID is aimed to realize the concept of balanced development between the rural and urban areas and the target users are local communities, students, youth, housewives and the elderly groups. PID was first

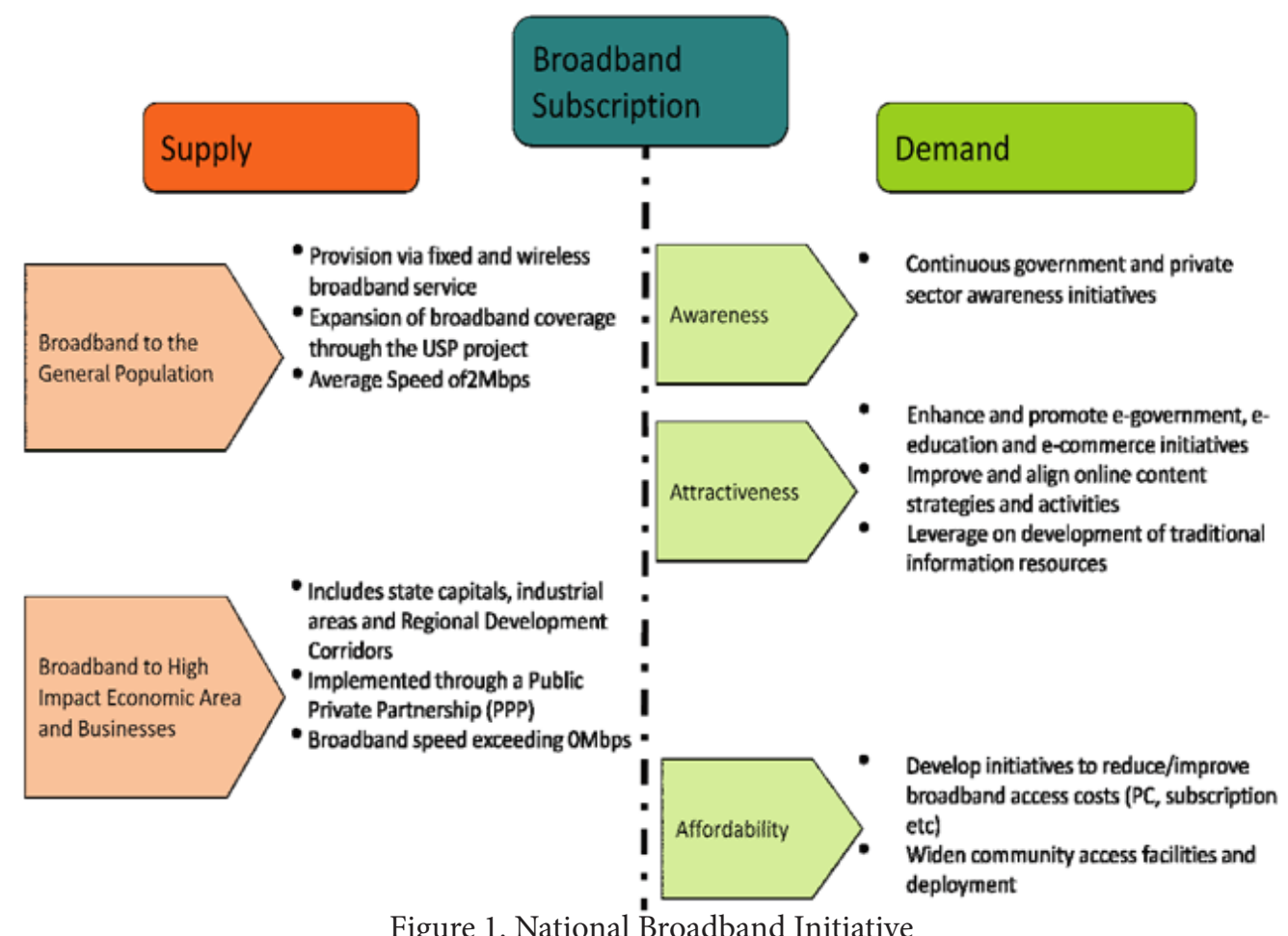

Figure 1. National Broadband Initiative

Source: mcmc.gov.my (2017) 
introduced in 42 centers in the year 2000 involving all the states excluding Wilayah Persekutuan. The services provided by PID are special education on using computers, obtaining Internet access, printing, and building website and centralized databases. Through the PID facilities from modern ICT, local communities can use the services with minimum fees (Abdul Manaf, 2012). PID is also one of the TC projects. As Jalaluddin (2014) notes, TC development in Malaysia started in 2000 initiated by the Ministry of Rural and Regional Development (KPLBW), Suruhanjaya Multimedia Malaysia (MCMC), Ministry of Energy, Water and Communications (KTAK) and state governments. In 2010 for instance, there were 1,945 TCs operating under various agencies.

In addition, various strategies are also undertaken to enhance the awareness of the population through government and private sector engagement and capacity development initiatives. The strategy is geared towards increasing demand whereby emphasis is given towards awareness, attractiveness and affordability level as illustrated in (Figure 1) below. In this context, various incentives for decreasing the cost of access to broadband and to expand the access of communication are taken into consideration to narrow down the digital gap (SKMM, 2017). One of the benefits of the broadband services is the creation of new economic opportunities in sectors particularly of local content development. Nevertheless, there are some obstacles when it comes to ICTs use and access in the rural communities. Among these, women are considered the more affected than men. In particular, as noted by Kelles-Viitanen (2003), women are disadvantaged when it comes to access for services and information such as technical, agricultural and market information. This can be attributed to their low educational status and high computer illiteracy, which incapacitates them from benefiting and tapping new information and improved practices from the digital technology.

Besides that, ICTs can change and revive old occupations and add on new public services to the local communities. As noted by Viitanen (2003), ICTs can benefit the poor by enhancing their activities and improving their productivity, whereby, this can be attained by increasing their access to market information or to lowering the transaction cost of the poor farmers and traders. Figure 2 below shows the ICT Development Index for Malaysia in the year 2017 as compared to the year 2016 that cover the element of access level, usage and skills of the communities. According to the Ministry of Communications and Multimedia (KKMM), Malaysia is ranked 63rd out of 176 countries in the 2017 Global ICT Development Index. As stated from the report in 2017, the percentage of households with Internet access was $76.86 \%$ and the percentage of individuals using the Internet was 78.79\% (ITU, 2017). Considerably this numbers are not critically low but there are some disparities in places that can be traced especially in the rural areas.

\section{The Methods}

The objective of this research was to explore the access to ICTs and its connection to poverty reduction in the northern region with particular emphasis on the northern state of the Peninsular Malaysia (Kedah state as a case study). Thus, focus is given to three elements of framework: (a) access to ICTs; (b) basic skills of ICTs; and (c) capabilities to use ICTs in daily work/activities. Primary data was obtained from a questionnaire survey conducted in SP and TD, which is considered as two locations with large differences in terms of social and spatial inequalities. Statistical data were obtained from the State Economic Planning Unit (UPEN) and other related government agencies and websites. The research is based on the collection of both quantitative and qualitative data from questionnaires and in-depth

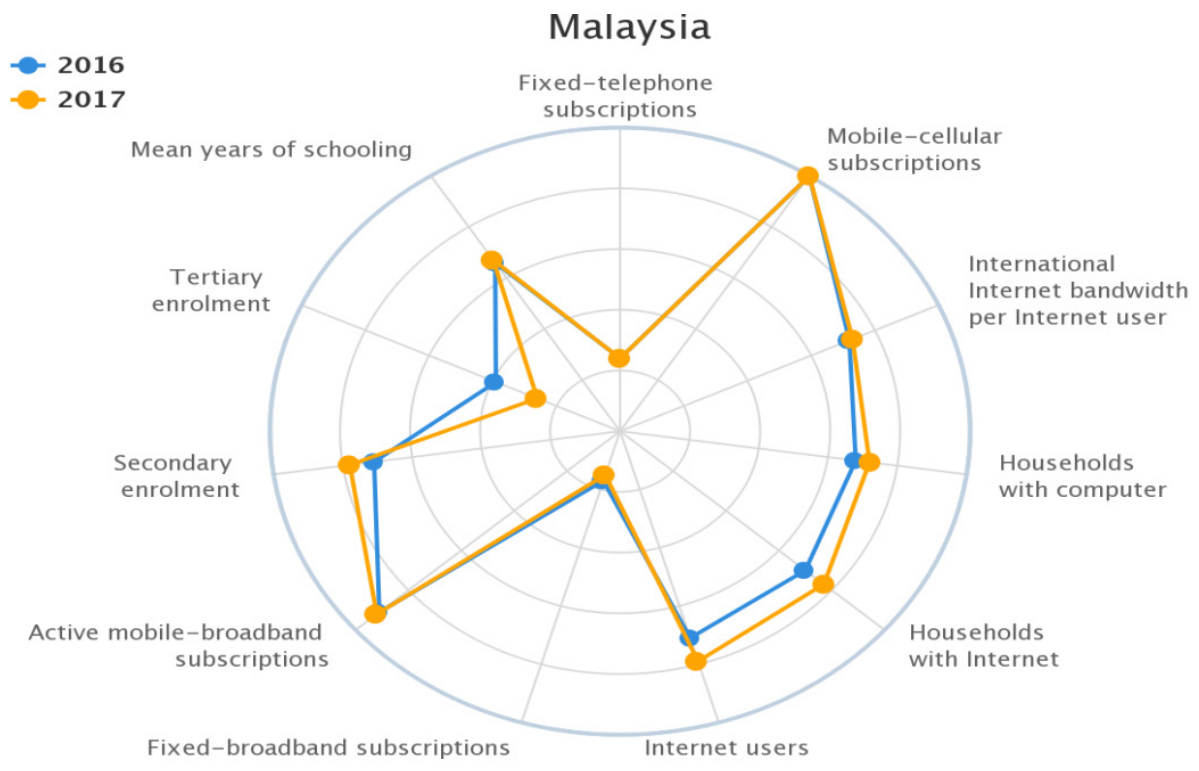

Figure 2. ICT Development Index for Malaysia 2017 


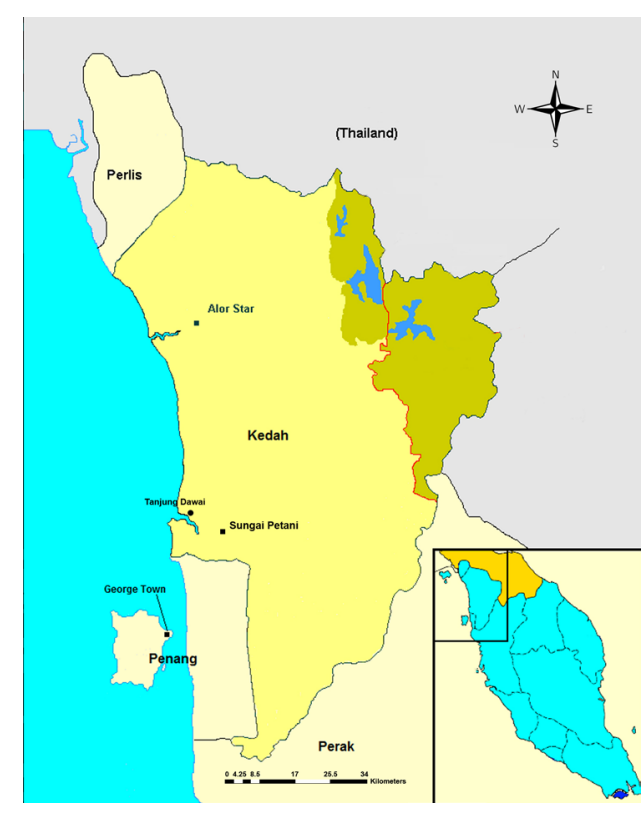

Figure 3. Location of the Study Area (Sungai Petani \& Tanjung Dawai)

interviews. Based on questionnaires and in-depth interviews, the focus was given to the rural and urban areas as stated above. A sample of 90 respondents was selected for the questionnaire survey. For this purpose, questionnaires were distributed to respondents in SP and TD, respectively. These respondents were selected randomly among the local communities residing in the residential areas and villages. They were mainly the head of the household or a member of the household whom is within the age group of 18-50 years old. Data were then analysed using SPSS. In-depth interviews were completed with five selected informants from TD and five informants from SP. The criteria for selection of informants are those within the working age group (18-50 years). This criterion was selected because this age group are those whom are mostly affected by the usage of ICTs.

The study is based on two locations, one in TD, which is a fishing village, and SP is a city area in the district of Kuala Muda. The location of the study area is illustrated in Figure 3 below. The Kuala Muda district has the highest population in the state, with approximately 458, 223 residents that are $21.0 \%$ out of the total population in Kedah for 2010. The majority of the population in TD is fishermen, fishmongers, and sea product entrepreneurs. It has a very small industrial area focusing on fish products, namely cottage industries. By contrast, in SP, most of the populations are working in the private sector and government agencies. Both areas are different in terms of spatial characteristics, economic activities and social strata of the population. The objectives of the study were to gather information about the perception and attitudes of the population towards ICTs usage in their daily activities and work purpose.

\section{Results and Discussion}

Table 1 below shows a summary of respondents' demographic and socioeconomic characteristics. For the socioeconomic strata, in particular with respect to income level of respondents, SP records the greatest number of respondents (14) with an income range of RM1001 - RM 2000. By contrast, for TD, the highest number of respondents is for the income range of < RM 500 (17). These results show a high level of income disparities between the two locations. The second highest income range was in TD is in the range of RM 500 - RM 1000 (12 respondents) and the second highest for SP is RM 2001- RM 3000 (12). Thus, these locations show quite a number of differences in terms of salary range between the two locations. In terms of education attainment, most of the respondents in SP (48.8\% or 22 respondents) had attained Sijil Pelajaran Malaysia (SPM) level, or the Malaysian Certificate of Education for their highest level of studies (which is equivalent to GCSE or O level). For TD, most of the respondents (44.5\% or 20 respondents) had completed their Penilaian Menengah Rendah (PMR), which is the lower secondary education certificate. For TD case, which is a fisherman village, most families were still living in remote areas and were far from the access to better education and better job opportunities and living condition. Most of the youngsters or the young residents left school at the age of 16 years old just to support their family for continuing the family business or work as a fisherman. This has also affected their lives in terms of limiting their level of skills and knowledge, and their socio-economic condition and quality of life. For employment, most of the respondents in both locations are self -employed (17 in SP and 23 in TD respectively). The second highest employment was for government servants in SP (15 respondents). Overall the income distribution, employment and education illustrate a sharp disparity between both locations. These coincide with the urban rural dichotomy in illustrating the socioeconomic disparities between the two locations.

Further analysis was completed based on the three elements of the study framework that covers: (a) access to ICTs; (b) basic skills, and (c) capabilities to use ICTs in daily activities.

\section{Access (ICT devices and connections)}

For the level of Internet connections/WiFi in the respondent's home between the two locations, respondents in SP reported better connectivity/access than those in TD. For instance, in SP there are 25 respondents with connectivity (20 without connectivity) whereas in TD is only 15 with connectivity (30 without connectivity). Meanwhile, the number of household with computer ownership shows a significant difference between SP and TD. For those who do not own a computer at home, there are 31 respondents (68.9\%) 
Table 1. Summary of Respondents Demographic/Socioeconomic Data.

\begin{tabular}{|c|c|c|c|c|}
\hline \multirow[t]{2}{*}{ RESPONDENT INFO } & \multicolumn{2}{|c|}{ SUNGAI PETANI } & \multicolumn{2}{|c|}{ TANJUNG DAWAI } \\
\hline & FREQUENCY & $\begin{array}{c}\text { PERCENTAGE } \\
(\%)\end{array}$ & FREQUENCY & $\begin{array}{c}\text { PERCENTAGE } \\
(\%)\end{array}$ \\
\hline \multicolumn{5}{|l|}{ GENDER } \\
\hline Male & 22 & $48.9 \%$ & 20 & $44.4 \%$ \\
\hline Female & 23 & 51.1 & 25 & 55.6 \\
\hline \multicolumn{5}{|l|}{ AGE } \\
\hline Less than 20 & 6 & & 11 & 24.4 \\
\hline $21-30$ & 7 & 13.3 & 10 & 22.2 \\
\hline $31-40$ & 14 & 15.5 & 6 & 13.3 \\
\hline $41-50$ & 9 & 31.1 & 11 & 24.4 \\
\hline $51-60$ & 9 & 20 & 2 & 4.4 \\
\hline more than 61 & - & 20 & 5 & 11.1 \\
\hline \multicolumn{5}{|l|}{ EDUCATION } \\
\hline UPSR & 3 & 6.7 & 5 & 11.1 \\
\hline PMR & 4 & 8.9 & 20 & 44.5 \\
\hline SPM & 22 & 48.8 & 11 & 24.5 \\
\hline STPM & 3 & 6.7 & 2 & 4.4 \\
\hline DEGREE & 4 & 8.9 & 1 & 2.2 \\
\hline MASTERS & 0 & 0 & 0 & 0 \\
\hline PHD & 0 & 0 & 0 & 0 \\
\hline OTHERS & 9 & 20 & 6 & 13.3 \\
\hline \multicolumn{5}{|l|}{ EMPLOYMENT } \\
\hline Government & & 33.3 & 6 & 13.3 \\
\hline Private Sector & 15 & 11.1 & 7 & 15.6 \\
\hline Self Employed & 5 & 37.8 & 23 & 51.1 \\
\hline Unemployed & 17 & 17.8 & 9 & 20.0 \\
\hline INCOME & 8 & & & \\
\hline$<500$ & 9 & 20.0 & 17 & 37.7 \\
\hline $500-1000$ & 4 & 8.9 & 12 & 26.6 \\
\hline $1001-2000$ & 14 & 31.1 & 10 & 22.2 \\
\hline 2001-3000 & 12 & 26.6 & 5 & 11.1 \\
\hline $3001-4000$ & 3 & 6.7 & 0 & 0 \\
\hline$>5000$ & 3 & 6.7 & 1 & 2.2 \\
\hline Total & 45 & 100 & 45 & 100 \\
\hline
\end{tabular}

Further analysis was completed based on the three elements of the study framework that

covers: (a) access to ICTs; (b) basic skills, and (c) capabilities to use ICTs in daily activities.

in SP and 38 respondents (84.4\%) in TD. Only seven respondents in TD had computers at home. The low ownership level for both areas correlates with level of salary and employment factor. Most computers are also costly to purchase and are not of high importance as compared to having a mobile phone.

Regarding the number of respondents with smart phone ownership, it is revealed that more respondents in SP owned smart phones than those in TD. The total number of respondents with smartphones in SP is 30 out of 45 respondents, whereas in TD is only 10 with smartphones out of 45 respondents. In addition, some of the respondents have also reported on the usage of TCs during the interview session. As stated by Informant 1 (fish product entrepreneur, age 37 ) in TD who spoke about the technology she uses:
"I seldom use the services at the center... I do not have time to go there. Every day I am occupied with my job and I prefer using my phone, it is not a smart phone though. When I am at work (business), it is all operated at home and I know well most of my customers. I call them directly and meet face to face with them. For my business, I just distribute the products at the local shops".

Some other respondents in TD have also mentioned that they are unaware of the services provided. Informant 2, a housewife (age 48) noted some reasons for her lack of awareness:

"My house is located further away from the tele-center. I also do not know how to use computers...I am not aware of the services at the center. Most women in this village are always busy with our daily work at 
home and taking care of the kids. In terms of time we have some constraint because we do not have enough time to go out for this and furthermore we do not know how to use the device and the Internet. Furthermore, my neighbors and friends do not go there; if they go I might follow them".

It is revealed that the Access to ICTs in both areas were influenced by the difference in geographic locations. Residents in SP, which is a growing city, reported much higher access to the Internet and ICTs than TD, which is a fishing village in the rural setting. In SP, people had higher incomes and were more educated, and thus, were more likely to purchase smart phones and computer literate. In the rural areas, the major problem was also physical access, particularly the availability of ICTs infrastructure. These areas had, especially the inferior hardware as compared with urban areas. As noted from previous studies - the pace of technological changes in Internet access can result in rural areas being permanently delayed in the implementation of the resources readily available in urban areas (see Kos-Labedowicz, 2017).

Nevertheless, the young adults have grown up and exposed with the digitally connected world and so they are to some extent familiar with the range of Internet enabled technologies and tend to use their mobile phones to communicate via social media platforms as well as using their mobile phones and text messaging functions but perhaps limited to more social interaction rather then for developing their socioeconomic conditions. However, the rural young adults also complained about poor coverage of the Internet line. One of the respondents also mentioned that sometimes the access to ICTs especially with respect to telecommunication infrastructure is quite a problem. As noted by Informant 3 who is one of the fish product distributor (male, age 27) noted about the sporadic coverage of the $3 \mathrm{G}$ phone coverage in his village that constraints his use of smart phone:

"It is troublesome because in some areas or streets where you can't get it at all and some places you have to get around even inside the house for places to get the line clear...the line is very bad and very slow sometimes. This is quite an obstacle especially when we have to rely on the phone for business orders."

In contrast, for residents in SP, which has both $3 \mathrm{G}$ and $4 \mathrm{G}$ phone coverage, it is more convenient and easily accessible for the communities to use the ICTs facilities for their daily usage/activities. Informant 4 who is a retail shop owner in SP (Male, age 35), commented and noted his reliance on his smart phone:

"Almost everyday I rely on my smart phone for business transactions and I do not have problems in terms of accessing to the Internet or Wi-Fi here". Everybody are using it, and if you don't, you are kind of left behind from the mainstream. In fact, I cannot operate without my phone....

\section{Basic Skills (individual know-how users)}

In terms of having basic skills and knowledge on using a computer and the Internet, it shows that most of the respondents in SP had better literacy and skills (88.9\%) as compared to those in TD (55.6\%), as shown in Figure 4. This correlates with the urbanized areas of SP where most of the communities have better access to IT education and a higher need for computer/internet usage. Most of the urbanites have basic to intermediate or advanced skills for using the computer, Internet and social media. Furthermore, as urbanization progresses, lifestyle changes and residents need to adapt to the new technology as elsewhere. People are getting more 'digital' in terms of business transactions, as well as social interactions and the nature of work (whether it is in the government or the private sector).

\section{Capabilities (ability for interactions through ICTs in daily activities)}

Table 2 shows that most of the respondents in SP (23) agree with using ICTs in business activities, while most of the respondents in TD (12) agree with using ICTs in day-to-day business activities. Most of the respondents in SP also strongly agreed (23) on the efficacy of using ICT to promote a new product to the market,

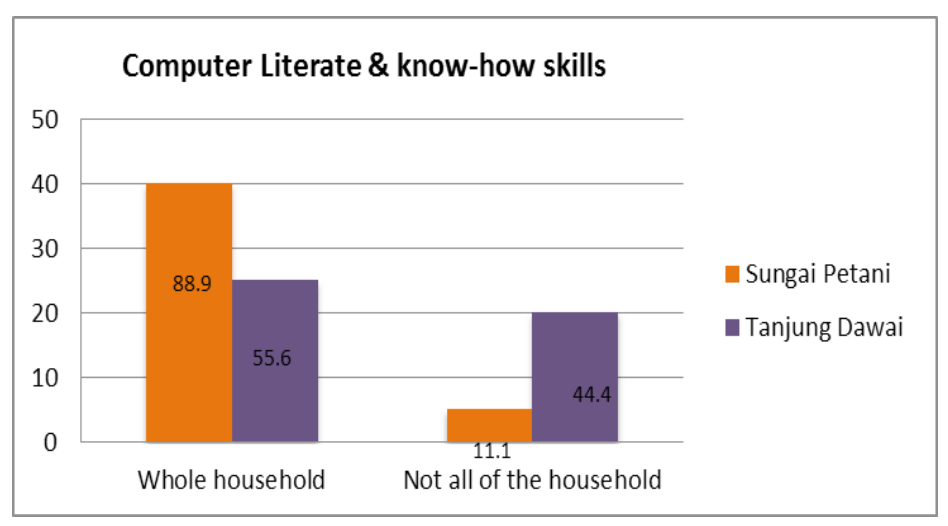

Figure 4. Household with computer literacy and know-how skills 
however in TD, most of the respondents disagreed (12). Meanwhile, respondents in TD agreed (12 respondents) that they like to share some of the information that they gained from the Internet and social media with their friends. By contrast, 21 respondents in SP strongly agreed with this. This information includes facts and information for business purposes such as market prices, and technology advancement of products and also about other day-to day interactions and activities. For example, Respondent 5 from TD (salted seafood entrepreneur, age 33) mentioned sharing information found online:

"I like to share the kind of information I get about marketing and selling my product outside this village. I tell my friends and family members, some of them do not know about it sometimes. I also travel outside to places like SP to market my products there. Our products are popular within the northern region... it is very fresh and reasonably priced".

However, Informant 5 also commented on the ICTs facilities in the village:

"...we have the internet center but I think it is not functioning as it should be... many things have to change. The villagers need more access to it and they need to be educated on ICTs and how to use it...especially for those who do not have the skills. Like you know we need to get more information about e-marketing and things like that. We have a lot of produce and entrepreneurs but we do not know how to market our product outside TD. I think with ICTs there is a lot of potential, but the quality need to be improved, the coverage upgraded and more skill training provided for the local entrepreneurs".

Figure 5 shows the frequency of using the Internet for searching information among the respondents. Both location shows very frequent level of usage (16 respondents for TD and 20 for SP). Although there is a tendency for usage among the respondents in TD and SP with slight differences, there are respondents who are still lacking in terms of their skills in using the social media for business purposes. Some of them especially the women and those who seldom obtain access to the internet/computer/ and smart phones are still lagging behind. As suggested by Informant 1(fish product entrepreneur, age 37):

"As women entrepreneurs we have very basic knowledge and we have left school at an early age. I personally think that many of the women in this village needs to be educated more in terms of getting access to new market and information for improving the local product. I think ICTs can help us but we need more education on this and improvement in facilities provided in this village".

The findings from this study revealed that there is some degree of digital divide in terms of access to ICTs among respondents/informants in SP and TD. However, it has to be noted that for TD case, the importance of having access to Internet was deemed crucial especially for the entrepreneur communities although not all of them are computer literate. More efforts are needed in order to enhance the basic skills and know-how of the communities especially in the rural locations like TD. The obstacles in terms of access such as in relation to the technological infrastructure and internet speed and so on have to be re-assessed by the government and various measures need to be taken to improve the situation in rural areas like this. The local communities are aware that little can be done by themselves to improve the level of connectivity in their area. If the situation is left unresolved, the urban-rural digital divide will become an unchangeable facet of exclusion facing the rural communities especially for those who are not affordable. In many cases, initiatives are taken by these local villagers themselves for instance purchasing mobile phones and getting data plan for internet connectivity especially for the younger generations, but this will need extra money for those who can afford financially and some basic skills in using digital devices and applications. For some others especially women

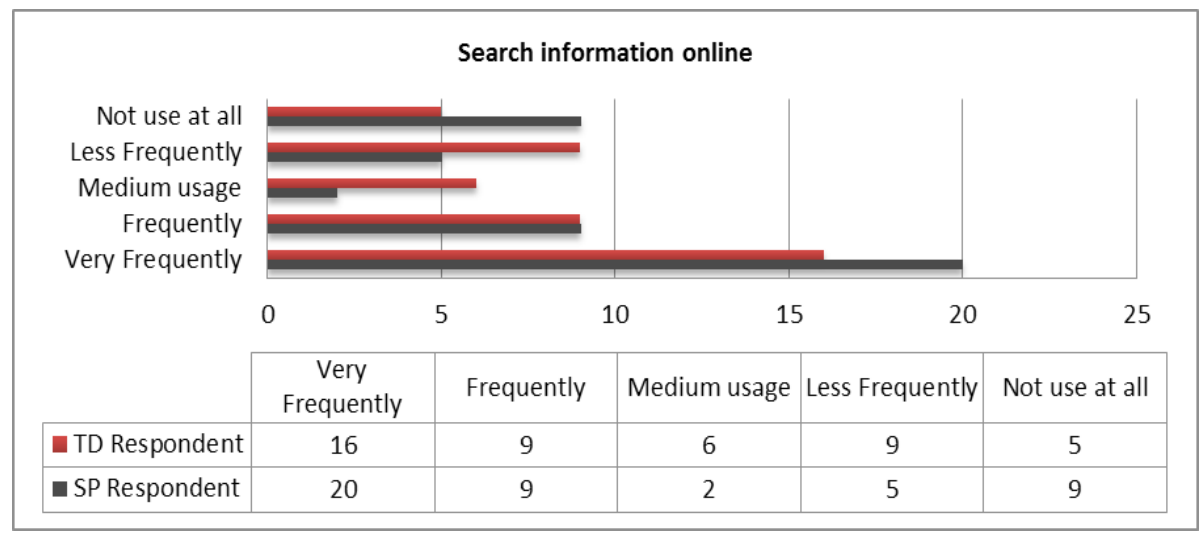

Figure 5. Frequency of using the Internet for searching information 
Table 2. Ability for ICTs mediated engagement in businesses

\begin{tabular}{lrrrrrr}
\hline Using ICTs in business activities & \multicolumn{5}{c}{$\begin{array}{l}\text { Using ICT to promote new prod- } \\
\text { ucts to the market }\end{array}$} & $\begin{array}{l}\text { Share new information on } \\
\text { the internet with friends }\end{array}$ \\
\hline SP & & TD & SP & TD & SP & TD \\
Strongly Agree & 15 & 10 & 23 & 10 & 21 & 10 \\
Agree & 23 & 12 & 20 & 10 & 13 & 12 \\
Not sure & 1 & 5 & 0 & 8 & 2 & 8 \\
Disagree & 3 & 10 & 0 & 12 & 5 & 11 \\
Strongly & & & & & & 4 \\
Disagree & 3 & 8 & 2 & & &
\end{tabular}

in their late 40s, there are problems encountered with their level of literacy and the limitation to the usage of ICTs in their daily activities.

Although there are PID or PI1M facilities provided for the communities, they do not use it that often and some are not aware of the services, or it is simply inconvenient to go for accessing the service. In many instances, youngsters/young residents and also those of other age groups only use it merely for social interaction and not for other more beneficial purposes in improving their socio-economic conditions. Although the PIDs/PI1M facilities are able to help expose the rural communities to the outside world, only small groups are involved. Mainly problem of access and distance to services, as well as communities' perception and attitude towards usage of the services could be a strong reason of why ICTs usage in areas like TD is limited to certain conditions. In addition, there is also a strong variation in terms of gender usage of the facilities and illiteracy level. Women are less likely to have good access to the technology or have the basic skills/know-how needed. In TD area, which is a fishermen village with potentially exportable local products and businesses, the involvement of the communities in using the ICTs is limited to the people who are engaged directly in businesses activities and can afford to have the devices. Others especially older housewife, the elderly and young children still have limited access to the services, thus suggesting a similar findings to what have been observed in the previous studies (Mendonca et al. 2015; Nemer, 2015). These are the areas that need further improvement. More efforts are needed to expose the villagers to the digital platforms and the way that businesses use them. ICTs programs and skill development are needed to educate the village entrepreneurs especially the younger generations on topics such as, e-marketing, multimedia workshops and using social media for businesses. This is crucial to enable them to stay competitive, and to transform their business, for instance their local products in order to penetrate a wider market.

In this respect, ICTs challenges must be addressed, that including the shortage of ICTs facilities and skills, limited financial resources, inadequate institutional arrangements, and inadequate communications and power infrastructure. There is also a need to enhance the engagement of public and private partnership in providing the services and facilities to promote ICTs in both the rural and urban areas. The rural communities realize that they are not able to do much to improve especially with respect to connectivity, access and usage of ICTs to improve their life. At the village level, there must be some efforts taken by the local governance to change the situation. The ability of the rural communities to jointly plan, obtain the necessary resources, and look across the needs to achieve better services and more sturdy technology infrastructure reveals the potential for community agents at different levels to respond to the uneven broadband market. Perhaps, there is a need for developing the crucial role of the localities and community in the establishment of broadband infrastructure that is responsive to the local situation and needs (see Philip et al 2017). This local community led local broadband services can respond to the inadequacies in broadband provision by commercial operators. As noted by Philip et al (2017), the Internet infrastructure developed by community led providers varies and the model adopted depends on the capacity of the communities, on funding and also geographical factors. This model and intervention can in fact be applied to the case of Malaysia, as it has been for other locations. Unless measures and action plans are taken particularly public bodies continued efforts to invest in digital infrastructure and policies to introduce acceptable alternatives to fixed broadband connections, the split between urban and rural communities will become even more prominent. For places like TD that has a lot of potential to develop, more efforts can be done in order to introduce the people to the use of ICTs more beneficially in terms of progressing their economic and business activities to the next level.

\section{Conclusion}

It can be concluded that there are territorial inequalities exist in digital infrastructure that are causing the urban-rural digital divide in the areas of TD and SP. These inequalities will have negative effects on the personal and business lives of residents especially in the rural areas. Nevertheless, ICTs have facilitated the flow of information and knowledge offering the socially 
marginalized and unaware communities unprecedented opportunities especially in improving their day-today activities. For SP and TD, the access, basic skills, and capabilities in ICTs usage has provided residents more opportunities to improve the socioeconomic conditions of the communities especially with respect to business expansion and poverty reduction. However, the digital divide does exists to some degree in some of the remote locations in which access is still a major issue, and disparity is evident between the richest and the poorest of the society.It is clear that the digital divide is largely due to inadequate infrastructure and local communities' inaccessibility towards better services and educational provisions. This divide will likely persist and may become more pronounced if private sector service providers prioritize new investments in urban areas and the public sector neglects an intervention to provide speedy broadband to all. Thus, concerted efforts by various government agencies, private sectors and the local communities are therefore necessary to ensure that the access to ICTs in both rural and urban areas are well outlined and carefully implemented. Closer engagement and collaboration from the village level to the state government (from the grass roots perspective) will help residents seize the benefits of ICTs and utilize them to accelerate the economic developments as they work towards achieving the SDGs, and in particular, to eradicating poverty. As highlighted by WeidmanGrunewald (2016), "Each SDGs is positively impacted by ICTs. By embracing broadband as critical infrastructure for the 21st century, we can create the foundations for unprecedented global social and economic progress". To break the vicious circle of rural poverty and to bridge the digital divide and empower the rural communities, an ICTs intervention has to be effective in the sphere of capacity building for rural communities to break the barriers. Barriers are found especially in terms of gender differences, literacy level and affordability in owning devices and obtaining network coverage. Improved understanding of affordability issues, innovating to reduce the cost of devices and services, improving network coverage, capacity and quality, and providing public access facilities are issues that need to be focused upon in terms of affordable access. Thus, the government, technology sectors and society should work together to deploy ICTs to accelerate economic and social development in rural areas. Concerted efforts by various government agencies, private sector and civil society are necessary to ensure that the access of ICTs in both rural and urban areas are well outlined and fully implemented. There is a need to implement sustainable measures to improve access to Internet and telecommunications infrastructure and increase ICTs literacy, as well as development of local internet-based content. The government for instance should focus upon improving the business environment through revision of regulatory and tax regimes to stimulate private sector led growth, and develop entrepreneurial business management skills of small business associations with emphasis on the urgent need to develop the ICTs skills among the rural communities. In this sense, a particular focus on the efforts undertaken from the grass root level will provide more opportunities for the rural people to succeed through ICTs intervention. More constant evaluation in terms of measuring the performance of mobile network services, fixed lines, wireless broadband and broadband cables should be taken into consideration. Therefore, an integrated framework for ICTs interventions in rural areas will pave the way towards sustainable rural growth and poverty reduction.

\section{Acknowledgement}

The authors would like to thank USM for providing grants to complete this research through the RUT research university grant (Spatial Inequalities: Framing Phenomena, Formulating Policies) and the RUI research university grant (Examining the Origins and Implication of Enclave Urbanism in the Iskandar Region of Johor, Malaysia).

\section{References}

Abdul Manaf Bohari \& Zainal Md Zan. (2012). Strategy of using wireless technology sophistication for rural community development. Journal of Asian Business Strategy 2(12), 284-290. Retrieved from https://www. academia.edu/4644654/Strategy_of_Using_ Wireless_ Technology_ Sophistication_for_Rural_Community_ Development_in_Malaysia

Bednarczyk, D. (2014). Counteracting digital exclusion (e-integration) in Poland. EBIB Newsletter. Collection and Protection of Digital Data, 9 (154), 1-12.

Blank, G. \& Groselj, D. (2015). Examining Internet use through a Weberian lens. International Journal of Communication, 9, 2763-2783.

Caspary, G., and O'Connor, D. (2003). Providing low cost information technology access to rural communities in developing countries: What works? What pays? WedDoc Series Working Paper. Paris, France: Organization for Economic Cooperation and Development (OECD) Centre, 1-35.

Castells, M. (2009). The rise of the network society (2nd ed.). West Sussex: Wiley Blackwell Publishing.

Castells, M. \& Gonzalez , F.(2014). The impact of the internet on society: A global perspective. In Change: 19 Key Essays on How the Internet is Changing Our Lives. Accessed from https://www.bbvaopenmind.com/en/ articles/the-impact-of-the-internet-on-society-a-globalperspective/

Castells, M. \& Himanen, P. (2014). Reconceptualizing development in the global information age. Oxford: Oxford University Press.

Chen, W. \& Wellman, B. (2005). Minding the cyber-gap: the Internet and social inequality. In Romero, M. \& Margolis, E. (eds). The Blackwell companion to social inequalities (pp. 523-545). Malden, MA: Blackwell Publishing.

Chinn, M. D., Fairlie, R. W. (2004). The determinants of the global digital divide: A Cross $\neg$ Country Analysis of Computer and Internet Penetration. Oxford Economic 
Papers New Series 59 (1), 16-44.

Correa, T. (2008). Literature Review: Understanding the "Second $\neg$ Level Digital Divide". Unpublished manuscript. Retrieved from https://www.academia. edu/212163/ Literature_Review_Understanding_the_second-level_ digital_divide_

DiMaggio, P., Hargittai, E., Neuman, W.R. \& Robinson, J.P. (2001). Social implications of the internet. Annual Review of Sociology, 27, 307-336.

International Telecommunications Union (ITU). (2017). ICT Development Index 2017. Retrieved from https://www. itu.int/net4/ITU-D/idi/2017/index.html

Ishak, M. S., \& Hassan, M. A. (2007). Keengganan memiliki komputer dan Internet di rumah: satu persoalan jurang digital dalam kalangan masyarakat Malaysia. International Conference on Media and Communication (MENTION 2007) in Noraidah Sahari et al. 2011. Kemudahan Capaian dan Penggunaan e-kerajaan di Malaysia. Prosiding PERKEM VI (1), 173-180. Fakulti Teknologi dan Sains Maklumat, Universiti Kebangsaan Malaysia.

Jalaluddin Abdul Malek. (2014). Kesertaan digital dan kelestarian telecenter pelbagai fungsi di Indonesia dan Malaysia. Malaysian Journal of Society and Space 8 (6), 166-183.

Kelles-Viitanen, A. (2003). The Role of ICT in Poverty Reduction. Working Paper. Finnish Ministry for Foreign Affairs.

Kos-Labedowicz, J. (2017). The issue of digital divide in rural areas of the European Union. Ekonomiczne Problemy Usług nr 1/2017 (126), t. 2. DOI: 10.18276/ epu.2017.126/2-20|

Loader, B. D. \& Keeble, L. (2004). Challenging the digital divide? A literature review of community informatics initiatives. York, UK: Joseph Rowntree Foundation.

Malecki, E.J. (2003). Digital development in rural areas: potentials and pitfalls. Journal of Rural Studies 19, 201214.

Mendonca, S., Crespo, N. \& Simoes, N. (2015). Inequality in the network society: An integrated approach to ICT access, basic skills, and complex capabilities. Telecommunications Policy 39, 192-207.

Muhammad Sani Bashir, Bahaman Abu Samah, Zahid Emby, HayrolAzril Mohamed Shaffril (2011). Impact of individual characteristics and telecenter Success in Malaysia. Australian Journal of Basic and Applied Sciences, 5(9), 371-380.

National Broadband Initiative. (2017). Accessed from mcmc. gov.my

Nemer, D. (2015). From digital divide to digital inclusion and beyond: A positional review. The Journal of Community Informatics 11(1): Retrieved from http://ci-journal.net/ index.php/ciej/article/view/1030
Nephew, H.S. (2006). Locating digital divides at home, work, and anywhere else. Poetics 34, 250-272.

Philip, L., Cottrill, C., Farrington, J., Williams, F. \& Ashmore, F. (2017). The digital divide: Patterns, policy and scenarios for connecting the 'final few' in rural communities across Great Britain. Journal of Rural Studies 54, 386-398.

Prieger, J.E. (2013). The broadband digital divide and the economic benefits of mobile broadband for rural areas. Telecommunications Policy 37, 483-502.

Rashid, A.T. (2016) Digital inclusion and social inequality: Gender differences in ICT access and use in five developing countries. Gender, Technology and Development 20(3), 306-332.

Riddlesden, D. \& Singleton, A.D. (2014). Broadband speed equity: a new digital divide? Applied Geography 52, $25-$ 33.

Skerrat, S. (2013). Hot spots and not spots: addressing infrastructure and service provision through combined approaches in rural Scotland. Sustainability 2, 1719-1741.

Sparks, C. (2013). What is the "Digital Divide" and why is it important? The Public 20 (2), 27-46.

Spitz-Oener, A. (2006) Technical Change, Job Tasks, and Rising Educational Demands: Looking outside the Wage Structure. Journal of Labor Economics 24 (2), 235-270.

Suruhanjaya Komunikasi dan Multimeida Malaysia. (2017). Komunikasi \& Multimedia Buku Maklumat Statistik 2013. Retreived from http://www.skmm.gov.my

Suruhanjaya Komunikasi dan Multimeida Malaysia. (2017). Komunikasi \& Multimedia Buku Maklumat Statistik 2014. Retrieved from http://www.skmm.gov.my Unsdsn. org.

Warren, M. (2007). The digital vicious cycle: links between social disadvantage and digital exclusion in rural areas. Telecommunication Policy 31 (6-7), 374-388.

Weidman-Grunewald, E. (2015) Ericsson and Earth Institute: ICT accelerates action on Sustainable Development Goals. Retrieved from https://www.ericsson.com/ en/news/2016/5/ericsson-and-earth-institute-ictaccelerates-action-on-sustainable-development-goals.

White, P. \& Selwyn, N. (2013). Moving on-line? An analysis of patterns of adult Internet use in the UK, 2002-2010. Information Communication Sociology 16 (1), 1-27.

van Dijk, J. \& Jan, A.G.M. (2006). Digital divide research, achievements and shortcomings. Poetics, 34(4-5), 221235.

Zurinah Tahir, Jalaluddin Abdul Malek \& Mohd Asruladlyi Ibrahim. (2016). Developing Smart ICT in rural Communities in Malaysia through the establishment of telecenters. e-Bangi Journal of Social Sciences and Humanities 11 (1), 227-242. 